BARANYAI Marcell

DOI: 10.15170/DIKE.2021.05.01.14

Kereskedelmi Jogi Diákkör

PTE ÁJK

\title{
A Német Szövetség váltójogi jogalkotása és annak hatása az Osztrák Császárságra és a Magyar Királyságra
}

\begin{abstract}
The Legislation of the German Confederation's Exchange Law and its Effect on the Austrian Empire and the Hungarian Kingdom

Among the 19th century's European legislative and codification processes nowadays' jurisprudence is happy to highlight the creation of civil codes as a milestone in the development of civil law, however, we must not forget the flourishing of another, at least as important branch of private law: the commercial law. In parallel with the growth of overland and sea trade, with increasingly diversified commercial relations, commercial transactions developed, which may have served as a good basis for the development of private law. This study is the first in a series of commercial law bistory studies and presents the sources of different laws on bills of exchange in the German territories and the harmonizing legislation of the thousand-faced German Confederation, as well as its impact on the Austrian Empire, such as the Austrian law on bills of exchange and the Hungarian Kingdom's vicious, but ultimately rewarding independent legislative aspirations.
\end{abstract}

Keywords: bill of exchange, legislation, German Confederation, Hansa, Austrian Empire, Hungarian Kingdom, commercial law, commerce

\section{Bevezető gondolatok a váltóról}

Az értékpapír az Isten saját képmására formált ember teremtőképességének egy ékes példája, egyúttal pénzügyi értelemben véve egyik legnagyobb vívmánya a szabadság jegyében. Az értékpapír különleges jogintézmény, amely tulajdonképpen egy dologi jogi köntösbe foglalt kötelmi jogi viszonyt testesít meg, ezáltal tesz forgalomképessé, adhatóvá és vehetővé. Ilyen értékpapír többek között a kötvény, a csekk, a részvény és az e tanulmány tárgyául választott, napjainkra méltatlan módon mellőzött váltó is. De hogyan kapcsolódik ehhez a szabadság és a teremtés?

Az emberek legtöbbjének nincs hatása egy adott nemzet valutájának árstabilitására, az infláció mértékére és az ezzel kapcsolatos politikára, a forgalomban lévő pénzmennyiségre, a nemzeti fiskális vagy monetáris politika részleteire, vagy azon gazdasági jogi jelenségek szabályozására, amelyek körül vesznek bennünket nap, mint nap. Az ember nem ura pénzének, csupán használója. Azonban - és itt mutatkozik meg a teremtés képessége - az értékpapírkibocsátás során olyan forgalomképes dolgok alkotására vagyunk képesek, amelyek nem függenek egyetlen a fentebb felsorolt jelenségre hatással bíró érdekcsoportok és közösségek pénzügyi centralizációs érdekétől. Gyakori panasz egy-egy hosszabb beszélgetés során, hogy „nincs elég pénzem”. A váltó 
azonban éppen e pénzhiány ellen hatásos gyógyszer. Ha a saját váltót vesszük példaként, akkor az értékpapír kiállítója fizetési kötelezettséget vállal az értékpapír rendelvényese - első jogosultja felé, ezzel hitelviszonyt hoz létre. A kifizetés ideje négy különböző megjelöléssel történhet: 1) a megtekintésre szóló váltó esetén bemutatáskor, 2) megtekintés után határozott időre szóló váltó esetén a kiállító - vagyis fizetésre kötelezett - aláírása után eltelt bizonyos napon, 3) a kelet után meghatározott időre szóló váltó esetén a váltó keltezése után megjelölt napon és végül 4) határozott időre szóló váltó esetén a megjelölt konkrét naptári napon. ${ }^{1}$ Ha a rendelvényes beváltja a váltóját, jogosult megkapni a váltón feltüntetett pénzösszeget és a kikötött kamatot, azonban ha nem kíván addig várni, úgy eladhatja vagy leszámítolhatja váltóját, ezáltal készpénzhez jut.

Hogyan lehet ez gyógyír a pénztelenségre? A címzett, például egy sörgyár által kiállított váltó, mint 200.000 forint összegú fizetési ígéret a rendelvényes tulajdonát képezi, ám az nem vár a címzettnél 30 nap múlva esedékes beváltással, inkább forgatmány útján átruházza egy helyi kocsmárosra, aki mint újdonsült kedvezményezett fizet érte a névértéknél kisebb, 190.000 forintot készpénzben, azonnal. A kocsmáros kivárja az esedékesség napját, majd beváltja a váltót, amiért a címzett a kikötött 6 százaléknyi kamattal együtt 212.000 forintot kap. A sörgyár ezzel nyert de facto 30 napnyi fizetési haladékot, a rendelvényes, aki elutazott kapott azonnal 190.000 forint készpénzt, illetve a kocsmáros kapott 212.000 forint készpénzt, amiből tiszta haszna 22 ezer forint. Ahelyett, hogy egyetlen pénzmozgás ment volna végbe a sörgyáros és a rendelvényes között, mint egy direkt kifizetés, kettő pénzmozgás ment végbe közel megduplázva ezzel a forgalomban lévő pénz mennyiségét. A váltó, mint a rétes, a címzett és a végső kedvezményezett között ahányszor gazdát cserél, annyi pénz teremtődik, kielégítve ezzel a fennálló pénzhiányt.

A váltó eredete nem tisztázott, azonban arról már egészen bizonyosan lehet tudni, hogy a 13. századi Itáliában a mindennapi kereskedelem részét képezte. Ebben a korszakban ÉszakItáliában aranykorukat élték a városállamok. Az európai gazdasági élet fontos szereplöje volt a Velencei Köztársaság, a félsziget közepén az erős Pápai Állam helyezkedett el, míg délen a „tengeri köztársaságok” folytattak élénk tengeri kereskedelmet. A váltó mint hitelviszonyt, pénzkövetelést megtestesítő értékpapír valószínűleg az ókori görög világban jelent meg és a Római Birodalom terjeszkedésével köthetett ki Itáliában², ám jogi szabályozása és ezzel első írásos említése egy ilyen jogviszonyt igazoló értékpapírnak Bologna város 1569-es statútumában található. ${ }^{3}$ Ekkoriban még nem beszélhetünk forgatmányról, amellyel átruházható lett volna a váltó, hanem egy bonyolultabb pólusú jogviszonyi rendszerrel szerkesztették meg az értékpapír értékesítési lehetőségét. 1897-ben a Pallas nagy lexikonában így írnak erről: „Eleinte a forgatmány célját, t. i. hogy egy más személy saját jogán, engedmény, vagy meghatalmazás nélkël érvényesithesse a váltót, az. $u . n$. négyszemélyes váltóval érték el, amelyen a kibocsátó, rendelvényes s intézvényezetten kivül egy praesentans neveztetett, ki a váltót a firetés helyén bemutatta s a váltói jogokat a maga részére érvényesithette. A 16. sæ-ban kezudödött a váltónak rendeletre való kiállitása s átrubázása külön átrubázó nyilatkozattal, melyböl a forgatmány származott." Itáliából valószínúsíthetôleg az európai szárazföldi kereskedelmi útvonalaknak köszönhetően juthatott el a váltó jelensége a

\footnotetext{
1 2017. évi CLXXXV. törvény 33. \$.

${ }^{2}$ Lásd FARKAS, Út az értékpapír Ptk.-ban újragondolt szabályozásáig, passim.

${ }^{3}$ Váltójog, https://mek.oszk.hu/00000/00060/doc/.

${ }^{4}$ Váltójog, https://mek.oszk.hu/00000/00060/doc/.
} 
Német-római Birodalom területére, ahol a császári szabad városok statútumaiban nyert írott formát, különös tekintettel a későbbi Hanza-városokra.

\section{A német területek egyes váltójogi normái}

A német váltójog kialakulásának gyöngyszemei azok a helyi jogi normák, melyek a kereskedelmi útvonalak találkozási pontjaiként szolgáló szabad városokban a 17-18. század fordulóján, illetve azt követően születtek: elsőként említhető az 1682-es lipcsei váltórendtartás, melyet az 1701-es danzigi, az 1706-os lübecki, az 1711-es hamburgi, az 1712-es brémai, az 1715-ös braunschweigi, az 1720-as szász-altenburgi, az 1723-as gothai, az 1724-es porosz és az 1726-os churpfalzi, valamint ugyanebből az évből a szász-weimari váltórendtartás követett. A 19. századi, második váltójogi jogalkotási hullámban - amely már nem csak városi, de állami szinten is tendenciaként értékelhető - beszélhetünk az 1822-es hannoveri, az 1844-es brémai, az 1862-es frankfurti, az 1864-es szász és a szintén 1864-es württembergi váltórendtartásokról is. ${ }^{5}$

A korszak első és egyben legnagyobb horderejü jogalkotása a váltójog területén, amely a német térség jogfejlődésére is nagy hatást gyakorolt, az 1673-as ordonnance de commerce volt. A XIV. Lajos által kiadott kereskedelmi törvényt rendszerint Code Savary-ként említi a szakirodalom, mivel az alapját a Jacques Savary műve, a „Parfait negociant” („Tökéletes kereskedô”) képezte, míg szellemi és gazdasági hátterét a colbert-i gazdaságpolitika teremtette meg. A kritika, mely szerint novum jellege nem is a tartalom újdonságában, hanem a szabályrendszer egységes jellegében és az általános területi joghatályában rejlik, annyiban helytálló, hogy a korábban keletkezett, sok esetben egymásnak ellentmondó coutume-jogokból válogatta ki a legmegfelelőbbeket és rendszerezte azokat. ${ }^{6}$ Ez a fajta jogalkotás, amely magában foglalta a váltójogi normákat is, a valós kereskedelmi igényeken alapult és olyan modern elvek jelentek meg benne, mint az egységesség, áttekinthetőség, szakmaiság, továbbá a szabályozó és szabályozottak közti együttműködés. Ez az első, a centralizáló abszolutista állam igényeihez igazodó kereskedelmi jogalkotás olyannyira jól sikerült és valósághủ volt, hogy egészen a napóleoni kereskedelmi kódexig, 1807-ig hatályban maradt, és modellként szolgálhatott a német térség számára is.

A térképre tekintve felmerülhet a kérdés, hogy a francia kodifikáció után kilenc évvel, 1682ben miért pont a német birodalom keleti határához közel, a szász Lipcsében készült el az elsô - és egyben a kortársak szerint legkiválóbb - német váltórendtartás. Érdemes a Hanza-szövetségből kiindulnunk, még ha az északi kereskedővárosok írott joga a lipcsei váltórendtartás után közel húsz, a francia kodifikáció után közel harminc év elteltével jelent is meg. A német nagyvárosok Hanzaszövetsége (unio hanseatica) létrejöttének pontos ideje kérdéses, az azonban tény, hogy a német kereskedők londoni szövetkezetének nyomai egészen Kr.u. 1000-ig vezethetők vissza. A kölni kereskedőknek szabadalmazott lerakodóhelye volt (Stahlhof vagy Stapelhof), amely a külföldön létesített hanzáknak szolgált alapul. Kölnhöz elsősorban a vesztfáliai városok, de nemsokára Lübeck városa is csatlakozott. A keleti-tengeri kereskedelemi szövetségbe 1241-ben Hamburg és nemsokkal utána Rostock, Wismar, később Stralsund és Greifswald városok csatlakoztak. Ekkoriban keletkezett a szász városok szövetkezete is, melynek a 14. század elején Lübeck és

\footnotetext{
${ }^{5}$ BABJÁK, A váltó fajai a 19. században 76.; NAGY, A magyar váltójog kézikönyve 28.

${ }^{6}$ NAGYNÉ SZEGVÁRI, A gazdasági jellegű jogintézmények kodifikációja a francia jogban 569-570.
} 
Hamburg is tagjai lettek. Nem elhanyagolhatók a porosz városok kereskedelmi szövetkezései sem a vesztfáliai hanzákkal 1340 óta. $^{7}$ A Hanza-szövetség befolyása a 17. században csökkeni kezdett az angolokkal való kereskedelmi viszály következtében, a hatalmas hálózat mindössze 14 város kisebb szövetségére szűkült vissza. Az egész szövetség az 1630-as utolsó Lübeckben tartott gyưlésen véglegesen föloszlott, azonban egyes országok, így főként Spanyolország és később Franciaország, hogy az Északi-tenger régióiban befolyásukat emeljék, továbbra is keresték az egykori szövetséges városok és különösen Lübecknek szövetségét. ${ }^{8}$ Összeségében tehát elmondható, hogy szoros összeköttetésben álltak az első váltójogi szabályozásra vállalkozó német városok, vagyis a Lipcse és Franciaország közötti távolság önmagában nem döntő tényező, mégis fontos tény, hiszen a kettő közti kereskedelem - és a jogtudomány legújabb vívmányai is - a Hanzaszövetség városain keresztül bonyolódott, ebből pedig egyenesen következik, hogy a Hanzavárosok is ismerhették és gyakorolhatták a váltó múködését, váltórendtartásaik pedig részben a francia hatásnak köszönhetően alakulhattak ki.

Ezt a következtetést támasztja alá a holland kereskedők esete is. Az 1566-os bálványrombolás után II. Fülöp parancsára 1567. augusztus 22-én Fernando Álvarez de Toledo, Alba hercege bevonul katonái élén Brüsszelbe, és kezdetét veszi a németalföldi szabadságharc, ${ }^{9}$ amelynek köszönhetően rengeteg antwerpeni polgár menekül el más északnémet városokba, ahol kereskedelmi tevékenységüket tovább folytatva ismertetik meg közvetlenül az 1670. évi antwerpeni

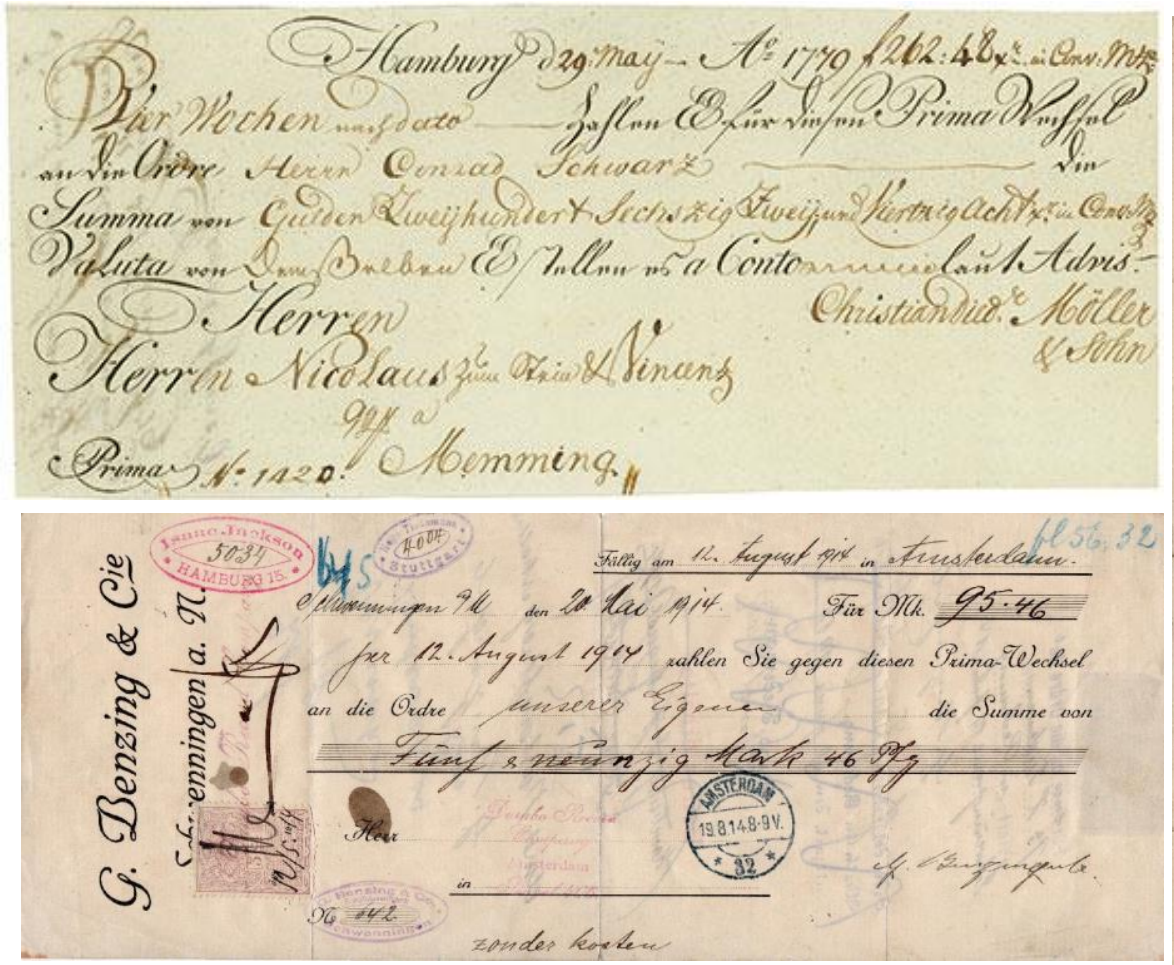

1-3. kép: Fent: 262,48 aranyra szóló hamburgi váltó 1779. május 29-i keltezéssel. Lent: 95,46 márkára szóló hamburgi váltó 1914. augusztus 12-i keltezéssel. Jobbra: Ugyanezen hamburgi váltó hátoldala a forgatmányokkal. Forrás: magángyűjtemény.

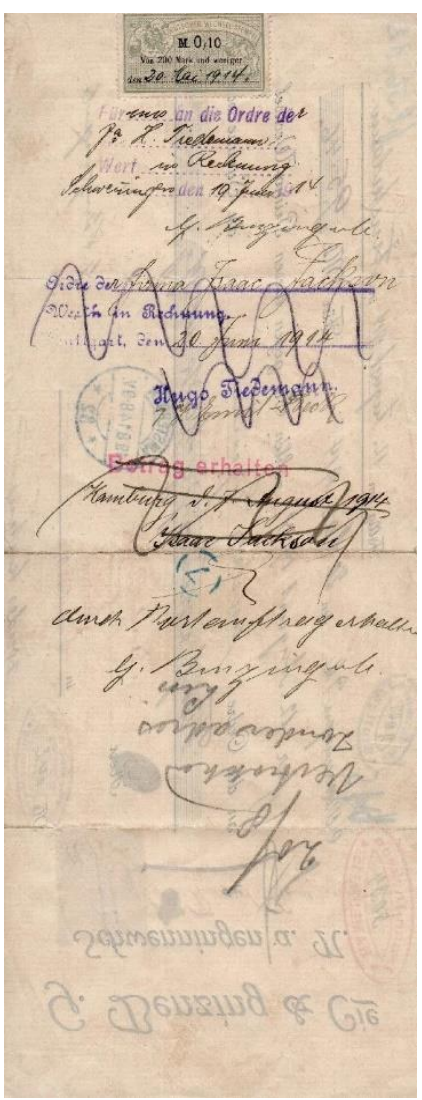

\footnotetext{
${ }^{7}$ Hanza, https://mek.oszk.hu/00000/00060/doc/.

${ }^{8}$ Hanza, https://mek.oszk.hu/00000/00060/doc/.

${ }^{9}$ Bővebben lásd VAN DER HORST, Nederland, de vaderlandse geschiedenis van de prehistorie tot nu, passim.
} 
váltórendtartás gyakorlatát a helyi német kereskedőkkel. ${ }^{10}$ Ha számításba vesszük, hogy Hamburgban már 1603-ban városi statútum rendelkezett a váltóról, a francia kereskedôk saját ordonnance-aik részesítették előnyben és a németalföldi holland kereskedők is saját joguk szerint gyakorolták a váltó jelenségét, akkor egy meglehetôsen színes képet kapunk, ami meglehetősen sok kútforrásból táplálkozó, erős váltójogi gyakorlatra mutat rá. Tulajdonképpen a Hanza-szövetség jelentette azt a biztos táptalajt a váltó mint jelenség elterjedésének, amely a pezsgô tengeri kereskedelemnek köszönhetően virágzásnak indult az északi régióban.

A fent felsorolt német váltórendtartások többféleképp csoportosíthatók. Európában alapvetően cselekvő és szenvedő váltóképességet különböztettek meg a váltórendtartások és a vonatkozó kereskedelmi törvénykönyvek, így a szenvedô váltóképesség a szerződési képességgel került összefüggésbe. A jogi normák közti legfőbb különbséget e képesség határának kiszabása jelentette, vagyis a korhatár. Így a szenvedő váltóképesség szempontjából az európai váltójogi normák első csoportjába tartozott az 1794-es porosz, az 1822-es hannoveri és az 1864-es württembergi váltórendtartás, amelyek szerint váltóképességgel csak az rendelkezik, akit a törvény ruház fel ezzel. Ez leginkább a kereskedők körét érintette, vagyis az átlag polgárok általában nem lehettek váltó alanyai. A második csoportot az 1701-es danzigi, az 1711-es hamburgi, az 1844-es brémai, az 1862-es frankfurti és az 1864-es szász váltórendszabályok alkották. Ezek a szerződési képességből eredeztetik a váltóképességet, ám kivételeket kötnek ki hozzá. A harmadik csoportba az 1681-es dán, az 1738-as sziléziai, az 1840-es magyar és az 1843-as osztrák váltótörvényeket sorolhatjuk. E törvények megkülönböztetik a saját illetve idegen váltót, és eszerint rendelik szabályozni a cselekvő és szenvedő váltóképességeket. ${ }^{11}$ A szabályozásbeli különbségek a társadalmi különbségeket is feltehetőleg magukon viselték, hiszen az írástudatlanok aránya a német területeken ez idő tájt $30 \%$ alatt volt, Franciaországban, az osztrák és a németalföldi területeken 30-50\% közé volt tehető, míg Magyarországon és Itáliában 50\% fölötti volt. ${ }^{12}$

\section{A Német Szövetség váltójogi jogalkotása}

A szövetségi jogalkotás elôtti idôszakban a váltók fokozatosan és folyamatosan gyarapodó szerephez jutottak a gazdasági életben, sőt katalizátorként múködtek a jólét növelésében és a kereskedelmi kapcsolatok fejlődésében. E korszak legnagyobb mérföldkövének a forgatmány megjelenését és elterjedését tekinthetjük, amely leegyszerűsítette a váltók átruházhatóságát, és ezzel a mûködését, valamint hozzájárult a felhasználói kör kiszélesedéséhez. A váltórendtartások 19. századi reformjának nagy eredménye volt, hogy elválasztódott a felek mögöttes szerződéses viszonya a váltójogi jogviszonyuktól, és az utóbbit csakis a váltótól, mint értékpapírtól tették függővé. ${ }^{13}$ A pezsgő kereskedelmi élet következtében nem csak a váltó intézménye virágzott, hanem a jogtudomány is fejlődésnek indult olyan jogtudósok révén, akik felismerték a kereskedelemi életet alakító jogi normák fontosságát. A német kereskedelmi jog, mint jogág megalapozását többek között Karl Christoph von Hofacker, Carl Einert, Heinrich Thöl, Levin Goldtschmidt és Konrad Cosack

\footnotetext{
${ }^{10}$ NAGY, A magyar váltójog kézikönyve 84.

${ }^{11}$ BABJÁK, A váltó fajai a 19. században 76.

${ }^{12}$ Cipolla, Literacy and Development in the West 79.

${ }^{13}$ CoING, Europäisches Privatrecht 568-569.
} 
végezte el. ${ }^{14}$ Hogy mennyire is volt mindennapi jelenség a váltó intézménye, azzal kapcsolatban érdemes Einert munkásságára egy pillantást vetni. Einert Lipcsében joghallgatóként ismerkedett meg a váltóval, a későbbiekben ügyvédként gyakorlati ismertekhez jutott annak használatól, amit jól kiegészített elméleti-dogmatikai tudása egyetemi tanárként és a mindennapi jogéletrôl szerzett tapasztalata Lipcse város tanácsosaként. Einert, aki 1841-ben állította össze a szász váltórendtartás tervezetét, a váltót „a kereskedök papirpénze ként” definiálta, „amely a magánszemélyek személyes bizalmán alapul, és amelynek visszaváltására a csilingeló pénz a garancia”. ${ }^{15}$ Einert műve tudományos szempontból a szövetségi jogalkotás előzményének tekinthető.

A Német Szövetségnek, noha 1815. június 8. óta fennállt, szövetségi szintű kereskedelmi joga nem volt egészen a megszűnése előtti ötödik évig, 1861-ig. A napóleoni Franciaország bukása után megalakult Német Szövetségben kifejezett szándék volt a német kereskedelmi jogegységesítés, ami azonban igen hosszú és nehézkes folyamatnak bizonyult. Ez a váltójog tekintetében sem volt másképp. A német egységen belül vezető erőnek számító Porosz Királyság meghívására Einert városában, az első váltórendtartást megalkotó szászországi Lipcsében ült össze a különböző tartományok és városállamok jogászi grémiuma azzal a céllal, hogy konzekvens, össznémet váltójogi szabályozást hozzanak létre, amelynek köszönhetően tovább élénkülne a németországi kereskedelmi élet és egységesülne a mindeddig partikuláris jog. A tanácskozási folyamat eredményeként született meg 1847-ben a Német Általános Váltórendtartás, vagyis az Allgemeine Deutsche Wechselordnung (ADWO). A jogalkotás alapját a francia Code de Commerce jelentette, amit azonban a német tervezet messze túlszárnyalt. A korszakban jellemzően a kereskedelmi törvénykönyvekben kapott helyet a váltójog, ́́gy a francia Code de commerce, a porosz Allgemeines Landrecht (ALR) kereskedelmi jogi része, a holland, a portugál, a spanyol és az itáliai kereskedelmi törvénykönyvek szabályozták a váltójogot. ${ }^{16}$ Kivételt a német váltórendtartás képezett 1848-as hatályba lépésével. S hogy ez mekkora jelentőséggel, bírt, arról Louis Nouguier francia kereskedelmi jogász nyilatkozata ad pontos képet: „Az uj német törvény rendszere elutasitja kereskedelmi kódexünk minden fó elvét. ${ }^{117}$ Ezzel a 19. századi váltójogi jogalkotásban két fő modell, a francia és a német megoldás elkülönült egymástól, de egyúttal mindkettő mintaként is szolgált Európa többi állama tekintetében.

De miben rejlett a német váltórendszer különlegessége? Az új német váltórendszabály célja volt, hogy szabványosítsa a váltóból, mint értékpapírból eredő jogviszonyokat, és azt elválassza a felek egyéb mögöttes szerződéses viszonyától, némileg szakítva is ezáltal az addigi hagyománnyal. Ennek eredménye, hogy sem az értéknapi záradékot, mint a váltó és a forgatmány követelményét, sem a francia jog által használt jutalék intézményét nem ismerte el. Az értéknapi záradék kihagyásának oka egész egyszerűen az volt, hogy a gyakorlatban a felek pusztán formalitásként kezelték, vagyis nem viselte magán valósághűen a felek között fennálló jogviszony sajátosságait. Új

\footnotetext{
${ }^{14}$ KECSKÉS, A polgári jog fejlődése a kontinentális Európa nagy jogrendszereiben 331-332.

${ }^{15}$ COING, Europäisches Privatrecht 569. Az eredeti szöveg szerint: „,das Papiergeld der Kaufleute, welches auf dem persönlichen Kredit von Privaten berubt, welche dessen Einlösung mit klingendem Gelde garantieren”.

${ }^{16}$ COING, Europäisches Privatrecht 569.

${ }^{17}$ KUNTZE, Deutsches Wechselrecht 254. Az eredeti szöveg szerint: „Le système de la nouvelle loi allemande répudie tous les grands principes de notre code de commerce".
} 
váltót kiállítására nem volt szükség akkor, ha a kiállítás helyszíne elhagyásra kerül, illetve a francia váltójoggal ellentétben formálisan is „Wechsel”-ként kellett megnevezni a váltót, azaz formai elő́rásokat fogalmaztak meg. ${ }^{18}$ Ekkor, a 19. század közepén sem a német vámunió tagországainak, sem a Német Szövetség tagjainak nem volt egységes magánjoga, így szükségesnek mutatkozott, hogy a váltórendtartás az tisztán a váltójogi szabályozásra terjedjen csak ki.

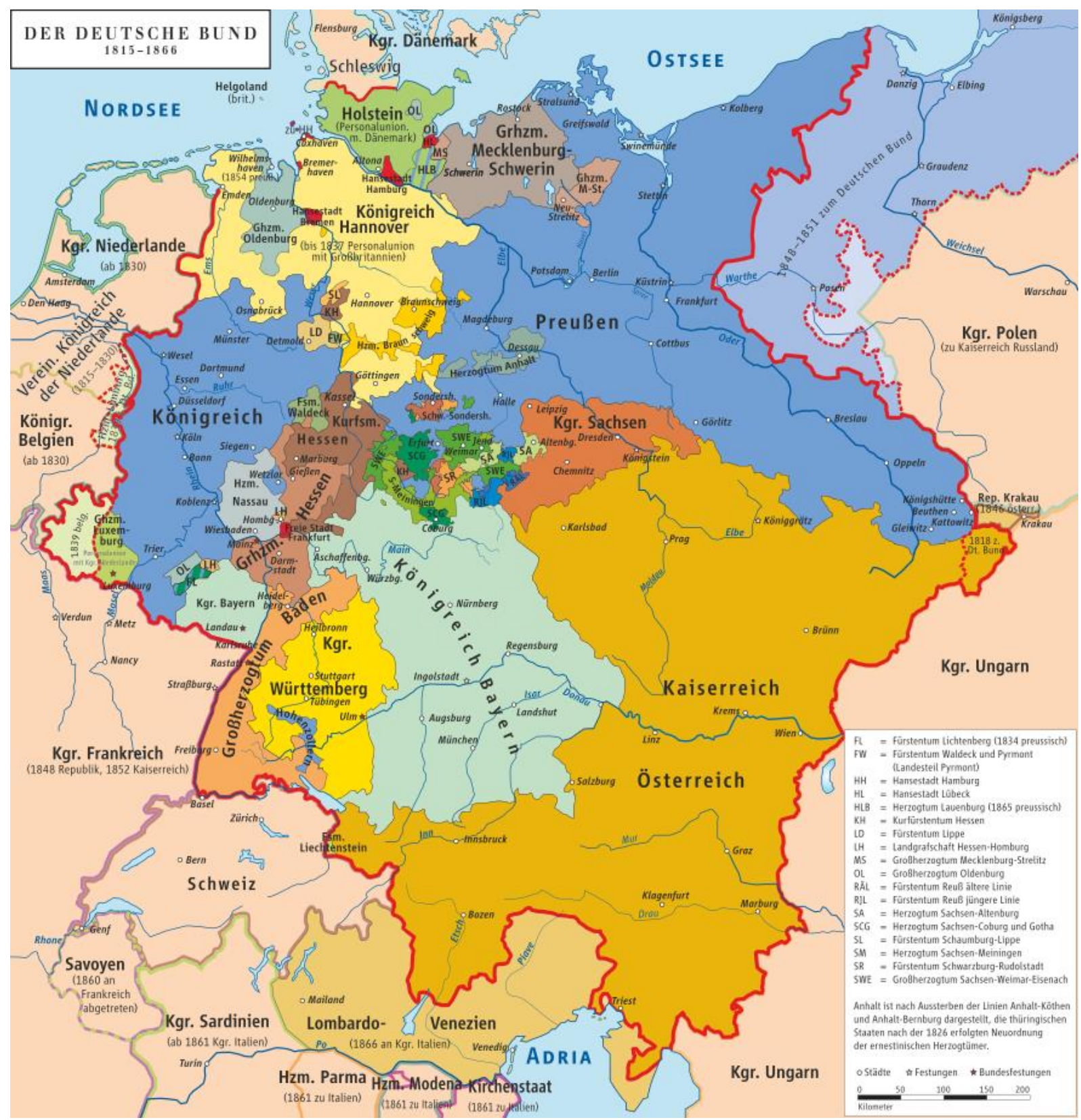

4. kép: A Német Szövetség térképe, 1815-186619

${ }^{18}$ COING, Europäisches Privatrecht 568-569.

19 Forrás: Von Ziegelbrenner, CC BY-SA 3.0, https://commons.wikimedia.org/w/index.php?curid=3414903 
Továbblépést jelentett a jogegységesítés tekintetében az 1856-os szövetségi gyűlés, melynek zárásaképpen bajor kezdeményezésre egy bizottságot állítottak fel azzal a céllal, hogy a Német Szövetség tagjainak egy új kereskedelmi törvényt alkossanak meg. A bizottság közel 4 év alatt Nürnbergben készítette el a kereskedelmi részekre vonatkozó, Hamburgban a tengeri kereskedelemre vonatkozó részeket. A nagy mú, az Allgemeines Deutsches Handelsgesetz̧buch (ADHGB), vagyis az Általános Német Kereskedelmi Törvénykönyv, amely az 1848-as váltórendtartást számos ponton kiegészítette, 1861. május 31-én hatályba lépett. ${ }^{20}$ Fontos eleme volt, hogy a törvény alapjául szolgáló porosz tervezetnek megfelelően a végleges szöveg is a kereskedelmi ügyletek közé sorolta a váltóügyleteket, amit azzal indokoltak, hogy a váltójog a váltóhasználat nem kereskedőkre történt kiterjesztése után is megtartotta kereskedelmi jellegét. ${ }^{21}$

A Német Szövetség Gyülése (Bundesversammlung) váltórendtartást, illetve a kereskedelmi törvénykönyvet is szövetségi joggá, majd a Német Birodalom közeli megalakulásával (1871) birodalmi joggá tette. Az ADWO egészen az 1930-as nemzetközi genfi váltójogi egyezménynek a hatályba léptetéséig (1933) érvényesült, közel száz éven át. ${ }^{22}$ Ehhez hasonlóan az ADHGB 1900-ig maradt érvényben, amíg a német polgári törvénykönyvvel (BGB) egyidőben 1900. január elsején az új kereskedelmi kódex $\left(\mathrm{HGB}^{23}\right.$ is hatályba lépett, normatartalmának túlnyomó részét a mai napig megőrizve.

\section{A német váltójog hatása az Osztrák Császárságra}

A váltó jogintézménye az osztrák területeken sem volt ismeretlen, különös tekintettel a közeli itáliai kereskedelmi útvonalakra és a tengeri, illetve az Alpokon túli kereskedelemre, hovatovább, a jogalkotási folyamatok megelőzték mind a franciákat, mind a németeket. Az 1705-ben császári pátenssel alapított bécsi városi bank 1707-ben kérvényezte az uralkodónál a bécsi kereskedőosztály érdekeire hivatkozva, hogy egységes váltójogi normát alkossanak és váltóbíróságot állítsanak fel. Indokaik között szerepelt az is, hogy a társaság más ügynökségei olyan városokban találhatóak, mint Antwerpen, Hamburg és Nürnberg, melyek saját váltórendtartással rendelkeznek, ezért különösen fontos, hogy egységes szabályok és azonos feltételek mentén tudjanak kereskedni és váltóügyleteket lebonyolítani. A kérés nem maradt válasz nélkül, 1717. szeptember 10-én hatályba lépett az első bécsi váltórendtartás (Wiener Wechselordnung), amely némi változtatással a frankfurti rendtartás átvétele volt.

Figyelemre méltó, hogy a bécsi szabályozás számos nem csak a váltókról rendelkezett, hanem más, kereskedelmiéletre vonatkozó előírásokat is tartalmazott. Többek között rendelkezett arról, hogy egy részvénytársaság alapításakor a részvényesek nevét rögzítsék és erről listát vezessenek. Ezt a szabályt később, 1725-ben a német-római trónt is birtokló Habsburg császár rendeleti úton megerősítette, így a kereskedelmi protokoll (Merkantilprotokoll) az első neveket ettől az évtôl tartalmazza. A bécsi rendtartás rendelkezéseit azonban a kereskedők nem tartották be

\footnotetext{
${ }^{20}$ Lásd ARENDT, Die Entstehung des Allgemeinen Deutschen Handelsgesetzbuches auf der Grundlage der Entwürfe Preußens und Österreichs. 13.

${ }^{21}$ NAGY, A magyar váltójog kézikönyve 88.

22 399/1933 RGBl.

${ }^{23}$ Lásd SCHMIDT, Münchener Kommentar zum HGB. 3.
} 
következetesen, és 1749-ben felszámolták a Kereskedelmi és Váltóbíróságot (Merkantil- und Wechselgericht) is. Hosszas udvari vizsgálatok után 1762-ben új és független bíróságot hoztak létre (Wechsel- und Merkantilgericht), majd a némileg átdolgozott rendtartást 1763-ban lefordították az örökös tartományok más népeinek nyelvére is, és a birodalom minden területén hatályba léptették. Ugyanebben az évben egy új rendelet is hatályba lépett (Wechsel-und Merkantilgerichtsordnung), amely a váltó és más kereskedelmi ügyletek bírósági perrendtartását határozta meg. Ez az eljárásjogi szabályozás később II. József uralkodása alatt többször is módosításokon esett át. ${ }^{24}$ Tehát jóval a francia és a német egységes váltójogi törekvések előtt az osztrák örökös tartományokban már írott és általános érvényủ váltórendtartás élt, amelyhez egységes váltóbírósági eljárásjog is társult.

Az általános osztrák váltórendtartás megalkotását - a Német Szövetség váltójogi jogalkotó tevékenységére és sikerére tekintettel, valamint azzal összhangban - I. Ferenc József rendelte el. A pátens, amely 1850-re készült el, bevezetô részében az uralkodó címeinek felsorolása után a következőt tartalmazza: „a kereskedelmi forgalom érdekében az egész. Monarchiára kiterjedő váltójog sürgető szülkségletében, és e fontos jogágban a törvényhozás a lehetö legnagyobb összhangban az osztrák jog és a német sqövetségi államok jogában hatályos általános német váltórendszabállyal elökészítendô, igazságügyi miniszterünk inditványára és Minisztertanácsunk tanácsára a birodalmi alkotmány 36. és 120. J-hoz képest az Osztrák Császárság egészére egy általános váltórendszabályt kibocsátandó, megitélendó és elrendelendô az alábbiak sžerint”. ${ }^{25}$ A történelem azonban úgy alakult, hogy I. Ferenc József osztrák császár és az Osztrák Császárság nélkül valósult meg a német egység 1871-ben, ami a német joggal való jogharmonizációnak és recepciónak is véget vetett. A hosszú életű uralkodót 1916-ban az osztrák trónon I. Károly követte. A birodalom 1918 őszén darabjaira hullott, és a helyén számos ország jött létre. Az 1918. november 12-én újjászületett Ausztria - a Weimari Köztársasághoz hasonlóan csatlakozott a genfi nemzetközi váltójogi egyezményhez. ${ }^{26}$ Az 1850 -es császári pátensen és az 1932 es genfi egyezményen alapuló osztrák váltójogi szabályozást 1954-ben kis mértékben, néhány külföldi országra vonatkozó elő́ŕrások tekintetében módosították csak, ${ }^{27}$ azaz továbbra is stabil eleme az osztrák magánjognak.

\section{A német és osztrák váltójog hatása a Magyar Királyságra}

Tagadhatatlan tény, hogy a Német Szövetség létrejöttével és az Osztrák Császárság, illetve a Porosz Királyság közti versengéssel a német egységen belüli vezető hatalomért, a kereskedelmi forgalom növelése érdekében a szövetségi jog harmonizációja kívánatosnak minősült Bécsben. Az osztrák váltójogi jogalkotást nagyban motiválta, hogy a Német Szövetség tagjaként az Osztrák Császárságban is jelen voltak a német kereskedők, bankárok, szállítók és a kereskedelmi élet egyéb szereplői. Társaságaik hálózatának kiépítése során a nagyobb német városok mellett az osztrák fövárosban is fióktelepeket és kirendeltségeket hoztak létre.

Az első bécsi bankok megalapításával a császárságban a kereskedelmi központ Bécs lett, miközben a nyugati államokban népszerű és bevett gyakorlatnak számító váltók, értékpapírok és

\footnotetext{
${ }^{24}$ Lásd WEDRAC, Die Anfänge der Wiener Handelsgerichtsbarkeit im 18. Jahrhundert 322.

${ }^{25} \mathrm{Az}$ 1850. január 25-én kibocsátott császári pátens eredeti szövege alapján fordította a szerző.

${ }^{26}$ Nr. 289/1932 BGB1.

${ }^{27}$ Nr. 240/1954 BGBl.
} 
hitelintézetek Magyarországon még várattak magukra. Mindez nem jelenti azt, hogy nyitási szándék és jogalkotó törekvések ne lettek volna: a Magyar Királyi Kúria - az 1763. évi osztrák váltórendtartást alapul véve - előkészített egy tervezetet, azt azonban sem az 1792-1795-ös, sem az 1825-1827-es reformországgyúlés nem tudta elfogadtatni.

A folyamatos magyar vívmányok és reformkövetelések viszont e területen is megjelentek, így 1839-ben az országgyủlés bizottságot alakított a magyar váltó- és hiteltörvények megalkotására, amelyekre úgy tekintettek, mint ami elengedhetetlen feltétele az ország fejlődésének. Az osztrák kancellária Metternich vezetésével Wildner Ignác osztrák ügyvédet bízta meg a Pozsonyba utazással és a magyar váltótörvények kidolgozásával. Miután a diéta mindkét háza elfogadta a rövid idő alatt megalkotott törvényjavaslatot és azt az uralkodó is szentesítette, az 1840. évi XV. törvénycikk 1840 júniusában lépett hatályba. ${ }^{28}$ Deák Ferenc így ír erről a követjelentésében 1840-ben: „A bitelnek és a kereskedésnek, melyek nélkül korunkban nemzet virágzó nem lehet, leghatalmasabb eszközei a váltók s legerósebb támaszai a váltótörvények." ${ }^{29}$ Habár az újonnan alkotott törvényt kiegészítették az 1844. évi VI. törvénycikk intézkedései, hosszú életnek nem örvendhetett. A neobaszolutista erőszakos jogexport keretében az 1850-es osztrák váltórendtartás hatályba helyezését a Magyar Királyságban az Országbírói Értekezlet zárta le. Az 1848 előtti magyar jog részleges helyreállítása a váltójog tekintetében nem váltott ki egybehangzó örömöt, mivel a kereskedôk egy része a nemzetközi kereskedelmi életre hivatkozva a német alapon nyugvó osztrák váltórendszabályt kívánatosnak tartotta volna érvényében meghagyni. ${ }^{30}$ Erdély valamivel különb utat járt be, hiszen az 1763-as osztrák váltórendtartás 1850-ig hatályban volt, amikor azt az új osztrák pátens váltotta fel.

A magyar kereskedelmi viszonyok könnyítése és felélénkítése érdekében napirendi pontként javasolták a kereskedôk az osztrák-német váltójogi szabályozás meghonosítását, így az 1867-es kiegyezés után - tekintettel az osztrák és magyar felek nagyfokú egymásrautaltságára - új jogalkotó folyamat vette kezdetét. 1873-ban a magyar igazságügyminiszter, Pauler Tivadar felkérte Apátby István egyetemi tanárt, hogy az osztrák mintát alapul véve új váltótörvénytervezetet készítsen el. Ugyan a tervezet lényegében megegyezett a mintával, mégis rendszerében eltért attól. A Képviselőház jogügyi bizottsága elé terjesztve módosításra került sor a tervezet rendszerén, hogy mindinkább összhangban legyen az osztrák szabályozással, illetve némi finomítások szükségeltettek. Egy korabeli, 1874-es újságcikkben ez olvasható a javaslatról: „Rendszere nem csak bogy a tudomány igényeit teljesen ki nem elégiti, hanem a kevésbbé tájékozottakra nézve az eligazodást is lényegesen megneheziti, mert nem követi mindenben biven a váltóügylet természetes lefolyását. Olyannyira, hogy az egyes jogtételek helyes alkalmazása nemcsak a váltójog elméletének, hanem azon szempontoknak kelló ismeretét is feltételezi, melyekböl a lipcsei tanácskozmány kiindult. És daczára a kiterjedt német literaturának, és judicaturának a fennforgó számos controversiát még a nürnbergi novellák sem birták teljesen megszüntetni. ’’1 A kellő módosítások és a két ház általi elfogadás után, 1876. június 12-én szentesítettvén kihirdetésre került az 1876. évi XXVII. törvénycikk a váltótörvényrôl. A törvény általános indoklásában ez olvasható: „E kö̈̃vetitöje a kereskedelmi forgalomnak a váltólevél, mely a pén żt helyettesiti és pótolja, söt némi tekintetben felette áll fontosságban, mert abstract képviselöje a bitelnek. Mint a kereskedelmi forgalom fizetési

\footnotetext{
${ }^{28}$ Váltójog, https://mek.oszk.hu/00000/00060/doc/.

${ }^{29}$ NAGY, A magyar váltójog kézikönyve 1.

${ }^{30}$ KAJTÁR - HergER, Egyetemes állam- és jogtörténet 305.

${ }^{31}$ Magyar Themis 1874/16 121.
} 
mediuma, a váltó minden ismert ügyleti formák közt a legmozgékonyabb és leghajlékonyabb: az egyaránt szolgálatában állhat az ǚlet minden képzelhetö nemének s nem csak fizetések. közvetitésére szolgál a legtávolabb belyeken; hanem együttal legkényelmesebb és legolcsóbb es₹këz, a nagyszerü kereskedelmi és iparvállalatokhoz. sұüleséges alap megszerzésére. ’’2 Az új magyar váltótörvény 1877. január elsejével lépett hatályba és kiterjedt mind Erdélyre, mind Horvát-Szlavónországra is, ezzel is komoly egységet teremtve, ahogy a magyar kereskedők részére, úgy a recepciós törekvések okán az osztrák kereskedők részére.

A dualizmus lázában égő jogtudósok jogalkotó tevékenysége tartósnak bizonyult. Ugyan az új, 1876-os váltótörvény kapcsán mindössze néhány szakasz tekintetében később módosításokat kellett végrehajtani, azonban a törvény egészen 1965-ig, az 1930-as genfi nemzetközi váltójogi egyezmény hazai recipiálásáig hatályban maradt és közel száz éven át biztos hátteret nyújtott a hazai kereskedelmi életnek. A második világháborúig virágzó váltóhasználat volt megfigyelhető hazánkban, legalább annyira szokványos volt, hogy valakinél váltó van, mint ahogy cigaretta. A különböző törvényjavaslatok és vélemények, sajtócikkek és indoklások halmazából kiválóan igazolódik, hogy a váltó jogintézménye bizony az emberek pénzhiányát volt hivatott orvosolni, kellő önállóságot és függetlenséget adott a kereskedelem és kereskedők részére, illetve megkönnyítette a hétköznapi ember mindennapjait is, mindezt sikerrel. A második világháború után szisztematikusan leépítették a váltó jogintézményét, nem támogatták használatát és kifejezetten kerülték mind a kereskedelemben, mind a gazdaság egyéb területein, mivel a politikai érdekekkel szemben állt megléte, sőt, mondhatni gátolta az elszegényedést, ráutaltságot. Magyarországon az ezeréves királyság romba döntésével és a kommunizmus megtelepítésével létrejövő új rendszer a korszellemhez képest viszonylag későn, a német és osztrák recepciók után több mint harminc évvel, 1965-ben vette át az I. törvényerejü rendelettel az 1930. június 7-én Genfben, a Nemzetek Szövetsége által megalkotott nemzetközi váltójogi egyezményt. ${ }^{33} \mathrm{~A}$ magyarországi rendszerváltoztatás után újra közel harminc év elteltével új váltótörvény született. A 2017. évi CLXXXV. törvény a váltójogi szabályokról 2018. január elejével lépett hatályba és számos apró, de nem lényegtelen módosítást eszközölt az 1965-ös normán. Ennek legfőbb oka a 2010 után kezdődött jogalkotási dömping, amely során az új, vagy javában módosított jogszabályokhoz mérten a váltójog is megreformálásra szorult. Lényegében egyes fogalmakat bontott ki és határozott meg a jogalkotó, mint például a leszámolóhely, az új polgári perrendtartással összhangba került a váltóperre vonatkozó szabályozás, illetve a kamat és késedelmi kamat tekintetében is történtek módosítások. ${ }^{34}$ Összességében tehát elmondható, hogy a magyar váltójog lényegi része nem változott az elmúlt évszád jogalkotásának tükrében, ugyanakkor minőségbeli módosítások és finomítások, részletezések történtek.

\section{Záró gondolatok}

E tanulmány egy kereskedelmi jogtörténeti tanulmánysorozat első részeként a váltót, mint értékpapírt annak feltételezett megjelenésétől a bevett európai használatáig terjedő időszakban mutatta be. Ebben a folyamatban kiemelkedő jelentősége volt a nagy német kereskedôvárosok és

\footnotetext{
32 Az 1876. évi XXVII. törvénycikk indoklása a váltótörvényről.

33 1965. évi I. törvényerejü rendelet.

34 2017. évi CLXXXV. törvény a váltójogi szabályokról.
} 
a Német SzÖvetség jogalkotó törekvéseinek és eredményeinek. Az olasz városállamok joga, a napóleoni kodifikáció és a korszak francia hódításai és ehhez társuló jogexportja hatására végbement jogharmonizáció, a német egység létrejöttéhez szükséges kereskedelmi jogi jogalkotás és hatalmi verseny, valamint a jogaiért és szabadságáért harcoló magyar nemzet önálló törvényhozási kísérletei és sikerei mind arról tanúskodnak, hogy a gazdasági fellendülésnek és az adott ország prosperálásának elengedhetetlen feltétele a kereskedelmi jog egységesítése, a kereskedelmi- és váltóügyletek életszerűvé alakítása, továbbá a kereskedői oldalról megfogalmazott igények meghallgatása és megbecsülése. Mára a váltóhasználat szinte teljesen kihalt Magyarországon. 1948 után a közhatalom elutasítóan viszonyult a váltóhasználathoz, és nem élvezett prioritást sem a jogalkotó, sem a pénzügyi közvetítőrendszer felett felügyeleti tevékenységet ellátó szerv részéről - szemben a hitel intézményével. Mindez mit sem változtat azon a tényen, hogy a váltó gyógyír a pénzhiányra, élénkíti és fejleszti a kereskedelmet és elérhetôbbé teszi a jobbmódot használói számára.

\section{Felhasznált irodalom és források}

ARENDT, Christopher: Die Entstehung des Allgemeinen Deutschen Handelsgesetzbuches auf der Grundlage der Entwürfe Preußens und Österreichs: die Berücksichtigung des österreichischen Entwurfes während der Nürnberger Beratungen von 1857 bis 1861. Innsbruck 2016

BABJÁK Ildikó: A váltó fajai a 19. században. Miskolci Jogi Szemle 2007/1. sz. 67-92.

Cipolla, Carlo M.: Literacy and Development in the West. London 1969

COING, Helmut: Europäisches Privatrecht II 19. Jahrhundert. München 1989

FARKAS Yvette: Ptk. Hatodik Könyv Ötödik Része - avagy út az értékpapír Ptk.-ban újragondolt szabályozásáig, gyakorlati szempontból. In: Tanulmányok a gazdasági jog, a pénzügyek és a számvitel köréből. Budapest 2016

VAN DER HORST, Han. Nederland, de vaderlandse geschiedenis van de prehistorie tot nu. Amsterdam 2013

KAjTÁr István - Herger Csabáné: Egyetemes állam- és jogtörténet. Budapest - Pécs 2015

KECSKÉS László: A polgári jog fejlődése a kontinentális Európa nagy jogrendszereiben. Budapest 2013

KUNTZE, Johannes Emil: Deutsches Wechselrecht. Leipzig 1862

Magyar Themis 1874/16. sz.

NAGY Ferenc: A magyar váltójog kézikönyve: különös tekintettel a bírói gyakorlatra és a külföldi törvényhozásokra. Budapest 1904

NAGYNÉ SZEGVÁRI Katalin: A gazdasági jellegű jogintézmények kodifikációja a francia jogban és hatásuk az európai jogalkotásra. In: Acta Universitatis Szegediensis: acta juridica et politica. Szeged 1996, 565-584.

N. n.: Hanza. In: In: Gerő Lajos (szerk.): A Pallas nagy lexikona VIII. köt. Budapest 1894 https://mek.oszk.hu/00000/00060/doc/ (letöltés: 2021. 07. 21.)

N. n.: Váltójog. In: Gerő Lajos (szerk.): A Pallas nagy lexikona XVI. köt. Budapest 1897 https://mek.oszk.hu/00000/00060/doc/ (letöltés: 2021. 07. 21.) 